\title{
Methyl-CpG-Binding Domain Protein 4
}

National Cancer Institute

\section{Source}

National Cancer Institute. Methyl-CpG-Binding Domain Protein 4. NCI Thesaurus. Code C106168.

Methyl-CpG-binding domain protein 4 (580 aa, $66 \mathrm{kDa}$ ) is encoded by the human MBD4 gene. This protein is involved in the DNA mismatch-specific glycosylase activity. 